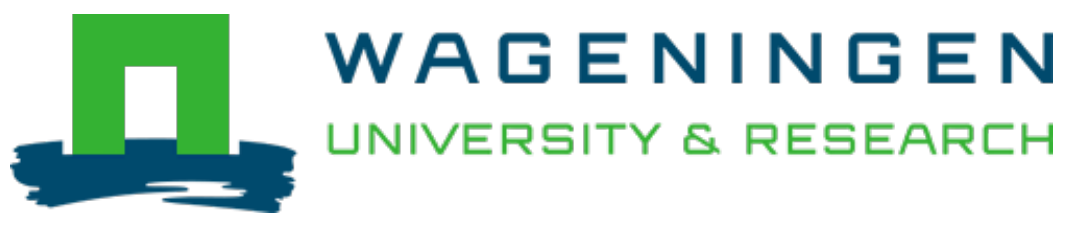

\author{
Diversity and functionality of Bacillus and related genera isolated from \\ spontaneously fermented soybeans (Indian Kinema) and locus beans (African \\ Soumbala) \\ International Journal of Food Microbiology \\ Sarkar, P.K.; Hasenack, B.; Nout, M.J.R. \\ https://doi.org/10.1016/S0168-1605(02)00124-1
}

This publication is made publicly available in the institutional repository of Wageningen University and Research, under the terms of article $25 \mathrm{fa}$ of the Dutch Copyright Act, also known as the Amendment Taverne. This has been done with explicit consent by the author.

Article 25 fa states that the author of a short scientific work funded either wholly or partially by Dutch public funds is entitled to make that work publicly available for no consideration following a reasonable period of time after the work was first published, provided that clear reference is made to the source of the first publication of the work.

This publication is distributed under The Association of Universities in the Netherlands (VSNU) 'Article $25 \mathrm{fa}$ implementation' project. In this project research outputs of researchers employed by Dutch Universities that comply with the legal requirements of Article $25 \mathrm{fa}$ of the Dutch Copyright Act are distributed online and free of cost or other barriers in institutional repositories. Research outputs are distributed six months after their first online publication in the original published version and with proper attribution to the source of the original publication.

You are permitted to download and use the publication for personal purposes. All rights remain with the author(s) and / or copyright owner(s) of this work. Any use of the publication or parts of it other than authorised under article $25 \mathrm{fa}$ of the Dutch Copyright act is prohibited. Wageningen University \& Research and the author(s) of this publication shall not be held responsible or liable for any damages resulting from your (re)use of this publication.

For questions regarding the public availability of this publication please contact openscience.library@wur.nl 


\title{
Diversity and functionality of Bacillus and related genera isolated from spontaneously fermented soybeans (Indian Kinema) and locust beans (African Soumbala)
}

\author{
P.K. Sarkar ${ }^{1}$, B. Hasenack, M.J.R. Nout* \\ Department of Agrotechnology and Food Sciences, Wageningen University, Bomenweg 2, 6703 HD Wageningen, The Netherlands
}

Received 24 June 2001; accepted 11 January 2002

\begin{abstract}
A total of 126 isolates of Bacillus and related genera from indigenous, spontaneously fermented soybeans (Kinema) and locust beans (Soumbala) were characterized with the purpose of defining interspecific, as well as intraspecific relationships among the components of their microflora. $B$. subtilis was the dominant species, and species diversity was more pronounced in Soumbala than in Kinema. While from Kinema, six species were isolated (B. subtilis, B. licheniformis, B. cereus, B. circulans, $B$. thuringiensis and B. sphaericus), in Soumbala, the species found were B. subtilis, B. thuringiensis, B. licheniformis, $B$. cereus, B. badius, Paenibacillus alvei, B. firmus, P. larvae, Brevibacillus laterosporus, B. megaterium, B. mycoides and B. sphaericus. Genomic diversity in the isolates of $B$. subtilis was investigated by random amplified polymorphic DNA (RAPD) analysis using the polymerase chain reaction (PCR). The RAPD-PCR fingerprint analysis showed a high level of diversity. With more than $90 \%$ similarity, all 52 RAPD subdivisions were source and continent-wise homogeneous. Profiles of carbon source fermentation also showed a wide but corresponding phenotypic diversity, largely corresponding with RAPD subdivisions. The various strains were tested for several criteria for functionality in soybean fermentation, viz. protein degradation, $\mathrm{pH}$ increase, and development of desirable stickiness caused by viscous exopolymers. Profiles of functionality, based upon estimations of $\mathrm{pH}$, free amino nitrogen and stickiness were associated with genotypic and phenotypic profiles. Notwithstanding the heterogenous fermentation results for some genotypic profiles, a ranking of RAPD groups is possible and can be useful in the further selection and study of B. subtilis strains. (C) 2002 Elsevier Science B.V. All rights reserved.
\end{abstract}

Keywords: Bacillus subtilis; Kinema; Soumbala; PCR; RAPD; DNA fingerprinting; Soybean fermentation; pH; Amino nitrogen; Stickiness

\section{Introduction}

Bacillus subtilis is an important starter culture for alkaline food fermentations. It is found predominantly

* Corresponding author. Tel.: +31-317-482834; fax: +31-317484978.

E-mail address: rob.nout@micro.fdsci.wau.nl (M.J.R. Nout).

${ }^{1}$ Present address: Microbiology Laboratory, Department of Botany, University of North Bengal, Siliguri 734430, India. in the production of certain important traditional fermented foods, such as Indian Kinema, Chinese Dou-shi, Thai Thua-nao, Japanese Natto and West African Soumbala. By hydrolyzing proteins to peptides and amino acids and releasing ammonia, the alkaline $\mathrm{pH}$ helps $B$. subtilis to dominate the fermentation by creating an inhibitory environment towards spoilage microorganisms. Alkaline fermentations also yield amino acid-peptide mixtures that are closely related to meat/protein food replacements as they 
provide the same amino acids for nutrition that meats provide following digestion and they also have a meat-like flavour, which contributes to food enjoyment (Steinkraus, 1995).

To make traditional Kinema, soybeans are washed, soaked overnight in water, boiled in fresh water until soft and crushed lightly to dehull. The grits are wrapped with locally available leaves and sackcloth and left to ferment for 1-2 days in a warm place (25$30{ }^{\circ} \mathrm{C}$ ) until the beans are covered with a stringy, mucilaginous coating and a typical Kinema flavour dominated by pyrazines is developed (Owens et al., 1997). Addition of a small amount of firewood ash to the crushed beans is optional. Kinema (Fig. 1a) is used to prepare a thick curry, eaten along with rice (Tamang et al., 1988).

In many of the West African countries, a fermented product of seeds from the African locust bean tree (Parkia biglobosa) is widely used as a condiment for preparing soups and stews. It is called Soumbala in

(a)

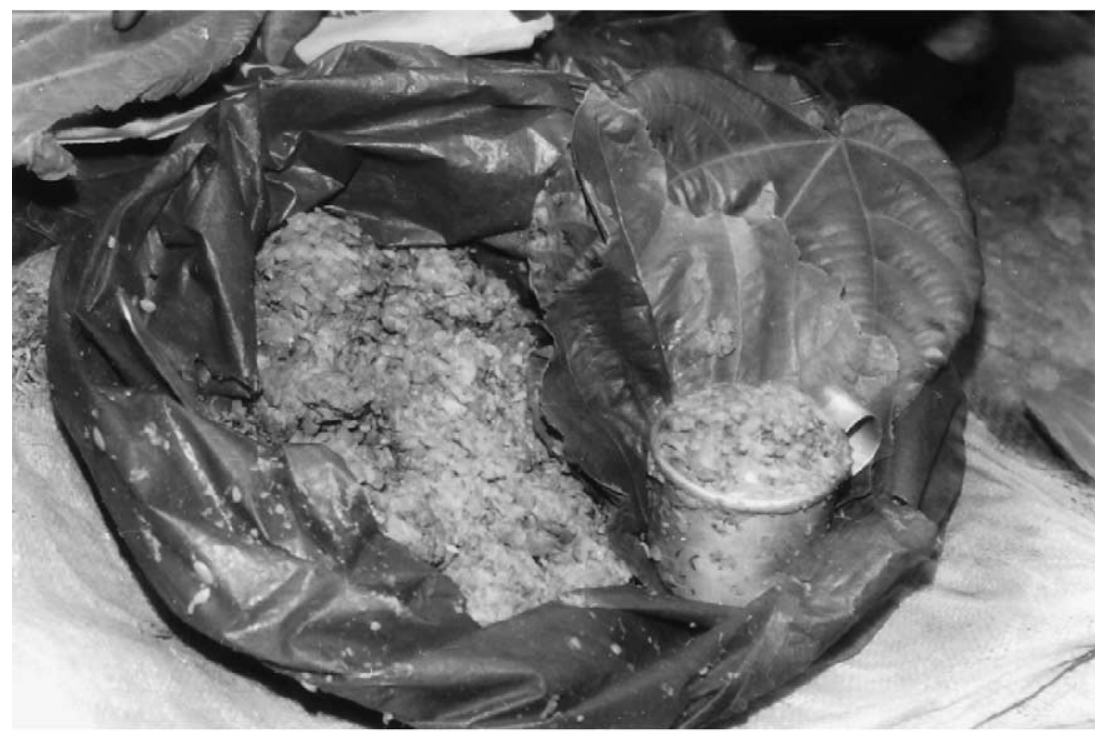

(b)

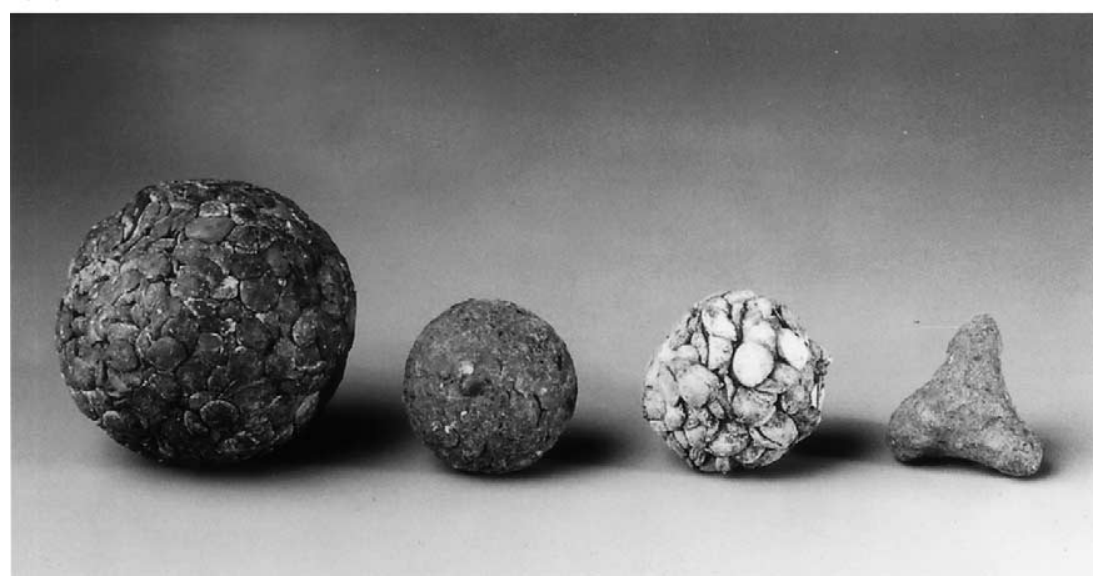

Fig. 1. Kinema (a) and Soumbala (b) samples. 
Burkina Faso and Mali, Soumbara in Ivory Coast, Nététou in Senegal, Dawadawa or Daddawa in Northern Nigeria, and Iru, Dorowa or Ogin-igala in the Savannah areas of Nigeria. The seeds are washed and boiled in water in a covered container for $18-24 \mathrm{~h}$ with occasional renewal of water to swell the seeds and soften the very tough seed coats which are then removed by pounding and flushing. The heap $(10-15$ $\mathrm{cm}$ thick) of cotyledons in a calabash is then covered with leaves and sackcloth and left to ferment for 3-4 days at ambient temperature $\left(25-35{ }^{\circ} \mathrm{C}\right)$ when the beans become covered in a sticky mucilaginous layer and develop a strong odour. The bean mass is air dried in the sun or hot shade, where the beans darken further to dark brown, and are then used loose or shaped into balls or pyramids (Fig. 1b). Wood ash is sometimes mixed to reduce the odour. To extend shelf life, salt is added in some areas (Campbell-Platt, 1987). Occasionally, soybeans also are used when locust beans are in short supply (Ogbadu and Okagbue, 1988a).

Both these fermentations are natural, i.e. no deliberate inoculation of the substrates with starter cultures is practised. It is likely that the environment and utensils become highly contaminated with a "house flora" that functions as an inoculum. Dominated by the rapid growth of the bacilli and the mucilage that is formed when the $\mathrm{pH}$ becomes alkaline, the invasion by other bacteria, yeasts and moulds is inhibited. Whereas B. subtilis, Enterococcus faecium, Candida parapsilosis and Geotrichum candidum are associated with Kinema (Sarkar et al., 1994), it is B. subtilis that has been found in all product samples in dominating numbers and that has been shown in pure culture experiments to be capable of the fermentation as a sole organism (Sarkar and Tamang, 1994; Sarkar et al., 1994; Tamang, 1999). Likewise, fermented locust bean products such as Dawadawa and Iru are dominated by $B$. subtilis in all samples (Odunfa, 1986) with concomitant presence of low numbers of opportunistic microorganisms such as Leuconostoc spp. (Antai and Ibrahim, 1986). B. subtilis has a record of safe use in vegetable protein foods (Odunfa, 1981).

Control of Kinema and Soumbala fermentations would serve the purposes of safeguarding product hygiene, as well as providing predictable organoleptic properties. A simple method was developed for the manufacture of pulverized soybean-grown pure culture starter for the Kinema process (Tamang, 1999).
To enable selection of starter cultures, criteria such as proteolytic activity, $\mathrm{pH}$ change and formation of flavour and texture can be used (Tamang and Nikkuni, 1996). In addition, it is important to know the exact composition of the natural product microflora and be able to characterize and distinguish it at a subspecies level. The conventional methods for identification of bacteria using morphological and physiological criteria are not always sufficiently discriminatory for this purpose. A valuable technique to enhance subspecies distinction is RAPD-PCR. This method has been successfully applied to Bacillus as well, and is considered as a discriminatory tool for measuring diversity among strains belonging to the same species (Brousseau et al., 1993; Stephan, 1996; Stephan et al., 1994).

The objectives of this study are to reveal diversity of Gram-positive spore-forming bacteria, particularly of $B$. subtilis, occurring in market samples of two spontaneously fermented alkaline foods, Kinema and Soumbala, originating from two different continents. In addition, functional fermentation characteristics $(\mathrm{pH}$, release of free amino nitrogen, stickiness) of these bacteria will be evaluated on soybeans and compared with their pattern of diversity.

\section{Materials and methods}

\subsection{Sampling}

Thirty-three samples (150-200 g) of spontaneously fermented Kinema were purchased from different retail shops in weekly markets of Gangtok, Darjeeling and Kalimpong, hill towns in West Bengal, the eastern part of India. Fourteen naturally fermented Soumbala cakes of different producers and with variable shapes were purchased at the central market of Ouagadougou, Burkina Faso. Fresh Kinema samples were collected in sterile polyethylene sampling bags, transported immediately to the laboratories in an icebox and analysed within 3 days of collection. Samples of dried Soumbala were stored refrigerated prior to analysis.

\subsection{Bacterial strains}

Representative $10 \mathrm{~g}$ portions of pasty Kinema or pulverized Soumbala were homogenized with $90 \mathrm{ml}$ 
sterile peptone-physiological saline $(0.1 \% \mathrm{w} / \mathrm{v}$ neutral peptone, $0.85 \% \mathrm{w} / \mathrm{v} \mathrm{NaCl}, \mathrm{pH} 7.2$ ) by the use of a Stomacher lab-blender 400 (Seward Medical, London, UK) for 1 min at 'normal' speed. Appropriate decimal dilutions $(0.1 \mathrm{ml})$ of the homogenates in the same diluent were spread over plates of nutrient agar (NA; M087, HiMedia Laboratories, Mumbai, India), tryptone soya agar or plate count agar (TSA: CM131; PCA: CM 325, Oxoid, Basingstoke, Hampshire, UK) and incubated at $30{ }^{\circ} \mathrm{C}$ for $24-48 \mathrm{~h}$. It was the objective to obtain as many different isolates a possible and, therefore, colonies were selected to represent the number of macroscopically different morphologies. Isolates were purified by dilution streaks on the same media. After microscopic examination of morphology, Gram-reaction and endospore formation, purified cultures were grown on slants of the same media and stored at $4{ }^{\circ} \mathrm{C}$.

The following isolates were obtained. From Kinema (working code in brackets): samples K1 (1-3), K2 (4-6), K3 (7-9), K4 (10-12), K5 (13-15), K6 (16-18), K7 (19-21), K8 (22, 23), K9 (24-26), K10 $(27,28), \mathrm{K} 11$ (29-31), K12 (32-34), K13 $(35,36)$, K14 (37), K15 (38-40), K16 (41-43), K17 (44-46), K18 (47), K19 ( 48-50), K20 (51, 52), K22 (53-55), $\mathrm{K} 23(56,57), \mathrm{K} 24(58,59), \mathrm{K} 25(60,62), \mathrm{K} 26(63-$ 65), K27 (66-68), K28 (69-71), K29 (72), K30 (7375), K31 (76-78), K32 (79), K33 (80), K34 (81, 82). From Soumbala: samples S1 (90-93, 94, 95), S2 (96-100, 101, 102), S3 (103-106), SA (107-109), SB1 (110), SB2 (111-113, 135), SC (114, 115), SD (116), SE (117, 132), SF (118, 119), SG (120-123, 134), SH (124-126), SI (131, 133), SJ (127-130). The following strains were used for comparative purposes: B. subtilis (natto) (code 61) "Miura" of Miyagino Natto Starter, Sendai, Japan, kindly provided by Dr. J.P. Tamang, Sikkim Government College, Gangtok, India; B. subtilis (code 83) DKW1 (MTCC-1747 Microbial Type Culture Collection, Chandigarh, India), B. subtilis (code 87) (ATCC6633 American Type Culture Collection, Rockville, MD, USA), B. licheniformis (code 84) (type strain, DSM-13 Deutsche Sammlung von Mikroorganismen, Braunschweig, Germany), B. badius (code 85) (type strain, DSM-23), B. pumilus (code 86) (type strain, DSM-27), B. cereus (code 88) (ATCC-12826) and (code 89) (ATCC-9139). In addition, Brevibacillus brevis (DSM-30) was used for primer selection.

\subsection{Phenotypic characterization}

Phenotypic characterization was performed according to Claus and Berkeley (1986) and Slepecky and Hemphill (1992) as summarized in Table 1. Nomenclature was updated according to Euzéby (1997).

\subsection{DNA isolation}

The method was based on the protocol of Mileham (1997), and the water used was demineralized and deionised. Briefly, cultures were grown on plates of TSA at $30{ }^{\circ} \mathrm{C}$ for $18-24 \mathrm{~h}$. One colony of about 3 $\mathrm{mm}$ diameter was suspended by vortexing at high speed in $0.5 \mathrm{ml}$ sterile water, contained in a sterile 1.5 $\mathrm{ml}$ Eppendorf tube. The suspension was centrifuged (9500g, $5 \mathrm{~min}$ ) and the supernatant discarded. The cell pellet was resuspended in $100 \mu \mathrm{l}$ InstaGene matrix (cat. no. 732-6030, Bio-Rad Laboratories, Hercules, CA, USA), incubated at $56{ }^{\circ} \mathrm{C}$ for $30 \mathrm{~min}$, vortexed briefly $(10 \mathrm{~s})$, again incubated at $100{ }^{\circ} \mathrm{C}$ for $10 \mathrm{~min}$, vortexed and centrifuged $(9500 \mathrm{~g}, 5 \mathrm{~min})$. The supernatant was transferred to a new sterile Eppendorf tube and stored at $-20{ }^{\circ} \mathrm{C}$ until further use.

\section{5. $R A P D-P C R$}

Based on the method described by Mileham (1997), a standard protocol was developed for amplifying reproducible RAPD fragments of Bacillus spp. genomic DNA. The two primers used (R1 and S1) were obtained after screening several primers of arbitrary base composition used for Bacillus (R1: 5' GAAGCAGCGTGG-3' with $T_{\mathrm{a}}, 35^{\circ} \mathrm{C}$ ) (Te Giffel et al., 1997) and Salmonella (S1: 5'-CCGCAGCCAA-3' with $T_{\mathrm{a}}, 30{ }^{\circ} \mathrm{C}$ ) (referred to as 1254 by Hilton et al., 1996). Reproducibility was tested by comparing fingerprints of duplicate DNA isolations of each type strain. The extracted DNA was amplified in a $50-\mu \mathrm{l}$ reaction mixture consisting of a mastermix and $0.5-$ $1.0 \mu \mathrm{g}$ template DNA in a thin-walled $0.5-\mathrm{ml}$ sterile microcentrifuge tube (cat. no. 179801, Biozym, Landgraaf, The Netherlands). The mastermix contained 10 mmol $1^{-1}$ Tris $-\mathrm{HCl} \mathrm{pH} 8.4,50 \mathrm{mmol} 1^{-1} \mathrm{KCl}, 1.5$ mmol $1^{-1} \mathrm{MgCl}_{2}, 200 \mu \mathrm{mol} 1^{-1}$ of each dNTP (Boehringer Mannheim, Mannheim, Germany), 1.5 U Taq DNA polymerase (cat. no. 18038-026, GibcoBRL, Life Technologies, Gaithersburg, MD, USA), 
Table 1

Phenotypical key used for tentative identification of Gram-positive endospore forming rod-shaped bacteria ${ }^{a}$

\begin{tabular}{|c|c|c|}
\hline \multirow{3}{*}{$\begin{array}{l}\text { (1) Allantoin or } \\
\text { urate required } \\
\text { (2) Catalase }\end{array}$} & $\begin{array}{l}\text { positive } \\
\text { negative }\end{array}$ & $\begin{array}{l}\text { Bacillus fastidiosus } \\
2\end{array}$ \\
\hline & positive & 3 \\
\hline & negative & 20 \\
\hline \multirow[t]{2}{*}{ (3) Voges-Proskauer } & positive & 4 \\
\hline & negative & 11 \\
\hline \multirow{2}{*}{$\begin{array}{l}\text { (4) Growth in } \\
\text { anaerobic agar }\end{array}$} & positive & 5 \\
\hline & negative & 10 \\
\hline \multirow[t]{2}{*}{ (5) Growth at $50{ }^{\circ} \mathrm{C}$} & positive & 6 \\
\hline & negative & 7 \\
\hline \multirow[t]{2}{*}{ (6) Growth in $7 \% \mathrm{NaCl}$} & positive & $\begin{array}{l}\text { Bacillus } \\
\text { licheniformis }\end{array}$ \\
\hline & negative & Bacillus coagulans \\
\hline \multirow[t]{2}{*}{$\begin{array}{l}\text { (7) Acid and gas } \\
\text { from glucose }\end{array}$} & positive & $\begin{array}{l}\text { Paenibacillus } \\
\text { polymyxa }\end{array}$ \\
\hline & negative & 8 \\
\hline \multirow{2}{*}{$\begin{array}{l}\text { (8) Reduction of } \\
\mathrm{NO}_{3}^{-} \text {to } \mathrm{NO}_{2}^{-}\end{array}$} & positive & 9 \\
\hline & negative & Paenibacillus alvei \\
\hline $\begin{array}{l}\text { (9) Parasporal body } \\
\text { in sporangium }\end{array}$ & $\begin{array}{l}\text { positive } \\
\text { negative }\end{array}$ & $\begin{array}{l}\text { Bacillus thuringiensis } \\
37\end{array}$ \\
\hline (10) Hydrolysis of starch & $\begin{array}{l}\text { positive } \\
\text { negative }\end{array}$ & $\begin{array}{l}\text { Bacillus subtilis } \\
\text { Bacillus pumilus }\end{array}$ \\
\hline \multirow[t]{2}{*}{ (11) Growth at $65^{\circ} \mathrm{C}$} & positive & 32 \\
\hline & negative & 12 \\
\hline \multirow{2}{*}{$\begin{array}{l}\text { (12) Hydrolysis } \\
\text { of starch }\end{array}$} & positive & 13 \\
\hline & negative & 17 \\
\hline \multirow[t]{2}{*}{$\begin{array}{l}\text { (13) Acid and gas } \\
\text { from glucose }\end{array}$} & positive & $\begin{array}{l}\text { Paenibacillus } \\
\text { macerans }\end{array}$ \\
\hline & negative & 14 \\
\hline \multirow{2}{*}{$\begin{array}{l}\text { (14) Width of } \\
\operatorname{rod} \geq 1.0 \mathrm{~mm}\end{array}$} & positive & 34 \\
\hline & negative & 15 \\
\hline \multirow[t]{2}{*}{ (15) Growth at pH 6.8} & positive & 16 \\
\hline & negative & Bacillus alcalophilus \\
\hline \multirow{2}{*}{ (16) $\mathrm{pH}$ in VP broth $<6.0$} & positive & 28 \\
\hline & negative & 26 \\
\hline (17) Growth in $10 \% \mathrm{NaCl}$ & $\begin{array}{l}\text { positive } \\
\text { negative }\end{array}$ & $\begin{array}{l}\text { Bacillus pasteurii } \\
18\end{array}$ \\
\hline \multirow[t]{2}{*}{$\begin{array}{l}\text { (18) Growth in } \\
\text { anaerobic agar }\end{array}$} & positive & $\begin{array}{l}\text { Brevibacillus } \\
\text { laterosporus }\end{array}$ \\
\hline & negative & 19 \\
\hline \multirow[t]{2}{*}{ (19) Acid from glucose } & positive & 30 \\
\hline & negative & 24 \\
\hline \multirow[t]{2}{*}{ (20) Growth at $65^{\circ} \mathrm{C}$} & positive & 33 \\
\hline & negative & 21 \\
\hline \multirow[t]{2}{*}{ (21) Growth in anaerobic agar } & positive & 22 \\
\hline & negative & $\begin{array}{l}\text { Bacillus } \\
\text { azotoformans }\end{array}$ \\
\hline \multirow[t]{2}{*}{ (22) Decomposition of casein } & positive & 35 \\
\hline & negative & 23 \\
\hline \multirow[t]{2}{*}{$\begin{array}{l}\text { (23) Parasporal body } \\
\text { in sporangium }\end{array}$} & positive & $\begin{array}{l}\text { Paenibacillus } \\
\text { popilliae }\end{array}$ \\
\hline & negative & 35 \\
\hline \multirow[t]{2}{*}{ (24) Growth at $50{ }^{\circ} \mathrm{C}$} & positive & Bacillus badius \\
\hline & negative & 25 \\
\hline
\end{tabular}

Table 1 (continued)

\begin{tabular}{|c|c|c|}
\hline (25) Growth at $5{ }^{\circ} \mathrm{C}$ & $\begin{array}{l}\text { positive } \\
\text { negative }\end{array}$ & $\begin{array}{l}\text { Bacillus insolitus } \\
\text { Bacillus sphaericus }\end{array}$ \\
\hline (26) Acid from arabinose & $\begin{array}{l}\text { positive } \\
\text { negative }\end{array}$ & $\begin{array}{l}\text { Bacillus lentus } \\
27\end{array}$ \\
\hline (27) Growth at $5{ }^{\circ} \mathrm{C}$ & $\begin{array}{l}\text { positive } \\
\text { negative }\end{array}$ & $\begin{array}{l}30 \\
31\end{array}$ \\
\hline (28) Growth at $5{ }^{\circ} \mathrm{C}$ & positive & $\begin{array}{l}\text { Paenibacillus } \\
\text { macquariensis }\end{array}$ \\
\hline & negative & 29 \\
\hline $\begin{array}{l}\text { (29) Growth in } \\
10 \% \mathrm{NaCl}\end{array}$ & positive & $\begin{array}{l}\text { Virgibacillus } \\
\text { pantothenticus }\end{array}$ \\
\hline & negative & Bacillus circulans \\
\hline (30) Hydrolysis of urea & $\begin{array}{l}\text { positive } \\
\text { negative }\end{array}$ & $\begin{array}{l}\text { Bacillus globisporus } \\
\text { Bacillus marinus }\end{array}$ \\
\hline (31) $\mathrm{pH}$ in $\mathrm{VP}$ broth $>7$ & $\begin{array}{l}\text { positive } \\
\text { negative }\end{array}$ & $\begin{array}{l}\text { Brevibacillus brevis } \\
\text { Bacillus firmus }\end{array}$ \\
\hline (32) Hydrolysis of starch & positive & 33 \\
\hline (33) Growth at pH 6.8 & $\begin{array}{l}\text { negative } \\
\text { positive }\end{array}$ & $\begin{array}{l}\text { Bacillus schlegelii } \\
\text { Bacillus } \\
\text { stearothermophilus }\end{array}$ \\
\hline & negative & $\begin{array}{l}\text { Alicyclobacillus } \\
\text { acidocaldarius }\end{array}$ \\
\hline $\begin{array}{l}\text { (34) Growth in } \\
\text { anaerobic agar }\end{array}$ & $\begin{array}{l}\text { positive } \\
\text { negative }\end{array}$ & $\begin{array}{l}\text { Bacillus thuringiensis } \\
\text { Bacillus megaterium }\end{array}$ \\
\hline $\begin{array}{l}\text { (35) Growth in } \\
10 \% \mathrm{NaCl}\end{array}$ & $\begin{array}{l}\text { positive } \\
\text { negative }\end{array}$ & $\begin{array}{l}\text { Bacillus pasteurii } \\
36\end{array}$ \\
\hline (36) Growth at $40{ }^{\circ} \mathrm{C}$ & $\begin{array}{l}\text { positive } \\
\text { negative }\end{array}$ & $\begin{array}{l}\text { Paenibacillus larvae } \\
\text { Paenibacillus } \\
\text { lentimorbus }\end{array}$ \\
\hline (37) Colony rhizoidal & $\begin{array}{l}\text { positive } \\
\text { negative }\end{array}$ & $\begin{array}{l}\text { Bacillus mycoides } \\
38\end{array}$ \\
\hline (38) Cells motile & $\begin{array}{l}\text { positive } \\
\text { negative }\end{array}$ & $\begin{array}{l}\text { Bacillus cereus } \\
\text { Bacillus anthracis }\end{array}$ \\
\hline
\end{tabular}

\footnotetext{
${ }^{\text {a }}$ Numbers on the right indicate the number (on the left) of the next test to be applied until the right-hand number is replaced by a species name (based on Claus and Berkeley, 1986; Slepecky and Hemphill, 1992; Euzéby, 1997).
}

and 25 pmol of each primer. The mixture was overlaid with a drop of sterile mineral oil (prod. no. M5904, Sigma, St. Louis, MO, USA) and capped. In each PCR assay, a negative control without any bacterial DNA was included. PCR with random primers was carried out in a DNA thermal cycler (Perkin-Elmer 480). The temperature profile started with initial denaturation for 5 min at $94{ }^{\circ} \mathrm{C}$, followed by 40 amplification cycles each consisting of $1 \mathrm{~min}$ at $94{ }^{\circ} \mathrm{C}$, annealing for $1 \mathrm{~min}$ at $35^{\circ}$ (primer R1) or $30^{\circ} \mathrm{C}$ (primer S1) and extension for $2 \mathrm{~min}$ at $72{ }^{\circ} \mathrm{C}$. After completion, reaction mixtures were cooled to $4{ }^{\circ} \mathrm{C}$.

A 25- $\mu$ l sample of the PCR product was mixed with $5 \mu$ l loading buffer consisting of $25 \%$ Ficoll-DL 
(Sigma F9378), $0.5 \mathrm{~g} / \mathrm{l}$ bromophenol blue (Sigma B5525), $0.5 \mathrm{~g} / 1$ xylene cyanol FF (Sigma X4126) and $1.0 \mathrm{~g} / 1$ orange $\mathrm{G}$ (Sigma O3756) and subjected to a submerged horizontal slab gel electrophoresis (BioZym) in a gel containing $1.6 \mathrm{~g}$ agarose (Seakem cat no. 50082, FMC Bioproducts, Rockland, ME, USA) in $100 \mathrm{ml}$ of TBE buffer $\left(0.089 \mathrm{~mol} \mathrm{l}^{-1}\right.$ Tris-HCl base, $0.089 \mathrm{~mol}^{-1}$ boric acid, 0.002 mol $1^{-1}$ EDTA, pH 8.0) and $0.5 \mu \mathrm{g} \mathrm{ml}^{-1}$ ethidium bromide (Sigma E1385) at $20{ }^{\circ} \mathrm{C}$ for $1.5 \mathrm{~h}$ at $90 \mathrm{~V}$, so that the bromophenol blue migrated about $75 \%$ of gel length. Bands were visualized on a UV transilluminator (Chromato-Vue Transilluminator model TM20, UVP, San Gabriel, CA 91778, USA) and exposed to a Polaroid film (Polapan Pro) for $12-15$ s. DNA molecular weight $(0.15-2.18 \mathrm{kbp})$ marker VI (Boehringer Mannheim) was used (final concentration 1.75 $\mu \mathrm{g} \mathrm{ml}^{-1}$ ) as size standard in each run.

For maximum accuracy of comparisons, all strains was processed with the same batch of mastermix and comparisons of highly similar RAPD patterns were based on common PCR batches.

\subsection{Fermentation of carbon sources}

The ability to ferment various carbon sources was determined using the API system (BioMérieux, Lyon, Marcy-l'Etoile, France) according to manufacturer's instructions. The cultures were grown on plates of NA (Oxoid CM3) at $30{ }^{\circ} \mathrm{C}$ for $16-18 \mathrm{~h}$. Cell material was harvested in $1 \mathrm{ml}$ sterile $0.85 \mathrm{~g} \mathrm{l}^{-1} \mathrm{NaCl}$ solution which was used to inoculate $10 \mathrm{ml}$ API $50 \mathrm{CHB}$ medium. The tubes of $50 \mathrm{CH}$ strips were filled with the inoculated medium, but the cupules were left blank. The strips were kept tilted at approximately $5^{\circ}$, bases of tubes uppermost, in order to trap any gas evolved, and incubated at $30{ }^{\circ} \mathrm{C}$ for $48 \mathrm{~h}$. The results were read at 24 and $48 \mathrm{~h}$; a test scoring positive at either reading time was considered positive.

\subsection{Data analysis}

The RAPD profiles (band patterns) in photographs were scanned. The data collected were normalized and further processed using the Molecular Analyst Fingerprinting v. 1.12 software (Bio-Rad) for generation of the cluster analysis in a dendrogram based on the Dice's similarity coefficient $\left(S_{\mathrm{D}}\right)$ and the unweighted pair group method using arithmetic averages (UPGMA). Interpretation of carbon source fermentation tests was carried out manually.

\subsection{Laboratory-scale soybean fermentation}

Soybean seeds of 'local yellow' variety, purchased from a grocery shop of a market in Siliguri town, were washed thoroughly with tap water and soaked in glass distilled water (water/beans, 4:1) for $16 \mathrm{~h}$ at ambient temperature $\left(25-28{ }^{\circ} \mathrm{C}\right)$. After decanting soak water, the beans were lightly crushed to make grits of mainly half-cotyledons. Approximately $75 \mathrm{~g}$ grits and $7 \mathrm{ml}$ soak water were taken into a $250-\mathrm{ml}$ screw cap bottle (Schott Duran, Germany), sterilized by autoclaving $\left(121{ }^{\circ} \mathrm{C}, 30 \mathrm{~min}\right)$, cooled to about $50{ }^{\circ} \mathrm{C}$, and inoculated to a concentration of $\log 7-8$ cells $\mathrm{g}^{-1}$ grits. For preparing inoculum, the test organisms were grown on nutrient agar slants at $37{ }^{\circ} \mathrm{C}$ for $24 \mathrm{~h}$. The cells were scraped off with a loop, suspended in $5 \mathrm{ml}$ sterile physiological saline $(0.85 \%$ sodium chloride in water) and agitated for 1 min using a Vortex mixer. Cell numbers were determined using a Neubauer counting chamber and a phase contrast microscope. The bottles were loosely capped and incubated for 24 h at $45{ }^{\circ} \mathrm{C}$ and approximately $90 \%$ relative humidity in an environmental chamber.

Table 2

Tentative identification of the 126 strains from Kinema and Soumbala, according to Table $1^{\text {a }}$

\begin{tabular}{|c|c|c|c|}
\hline & $\begin{array}{l}\text { Kinema } \\
\text { isolates }\end{array}$ & $\begin{array}{l}\text { Soumbala } \\
\text { isolates }\end{array}$ & Total \\
\hline Paenibacillus alvei & & 1 & 1 \\
\hline Bacillus badius & & 2 & 2 \\
\hline Bacillus cereus & 2 & 3 & 5 \\
\hline Bacillus circulans & 2 & & 2 \\
\hline Bacillus firmus & & 1 & 1 \\
\hline Paenibacillus larvae & & 1 & 1 \\
\hline Brevibacillus laterosporus & & 1 & 1 \\
\hline Bacillus licheniformis & 3 & 3 & 6 \\
\hline Bacillus megaterium & & 1 & 1 \\
\hline Bacillus mycoides & & 1 & 1 \\
\hline Bacillus sphaericus & 1 & 1 & 2 \\
\hline Bacillus subtilis & 73 & 24 & 97 \\
\hline Bacillus thuringiensis & 2 & 4 & 6 \\
\hline Total & 83 & 43 & 126 \\
\hline
\end{tabular}

\footnotetext{
a Data represent the number of strains tentatively identified.
} 


\subsection{Functional properties}

Strains exhibiting growth to at least $\log 9 \mathrm{cfu}^{-1}$ grits were tested for their effect on soybean $\mathrm{pH}$, release of free amino nitrogen and stickiness.

\subsubsection{Determination of $\mathrm{pH}$ and free amino nitrogen}

According to Nout et al. (1998), an accurately known weight of about $5 \mathrm{~g}$ fermented beans was homogenized with $\mathrm{CO}_{2}$-free glass distilled water to a total volume of $20 \mathrm{ml}$. The $\mathrm{pH}$ of this suspension was measured using a conventional glass/calomel electrode. On a magnetic stirrer, the $\mathrm{pH}$ was subsequently increased to 8.5 using $0.1 \mathrm{M} \mathrm{NaOH}$. After

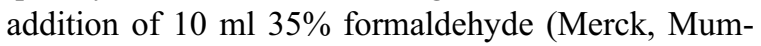
bai, India), the suspension was stirred for $2 \mathrm{~min}$, and the released protons were titrated using $0.1 \mathrm{M} \mathrm{NaOH}$ till the end-point $\mathrm{pH} 8.5$ was reached. Free amino nitrogen (FAN) content was calculated on the basis of stoichiometric equivalence of one $\mathrm{NaOH}$ and one amino group.

\subsubsection{Determination of stickiness}

Samples of approximately $40 \mathrm{~g}$ fermented beans were stirred in a rotary movement at constant speed for $1 \mathrm{~min}$ on a dry metal plate, using thumb and index finger which were kept approximately $4 \mathrm{~cm}$ apart. After stirring, the two fingers were pressed together for $1 \mathrm{~s}$ and separated again. The length of the sticky threads that were pulled was measured at their breakpoints.

\section{Results and discussion}

Bacillus spp. are the organisms responsible for alkaline food fermentations and spoilage of foods in general due to their versatile metabolism and heatresistant spores (Deák and Timár, 1988; Steinkraus, 1995). Hence, information about Bacillus spp. would be of primary importance in monitoring fermentation and good manufacturing practice. The lack of a complete key to the identification of Bacillus strains

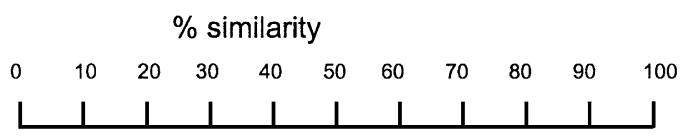

$\begin{array}{lrcc} & \mathrm{n}^{1} & \text { AVG }^{2} & \text { S.D. } \\ & & & \\ & & & \\ \mathrm{A} & 1 & 3.0 & - \\ & 5 & 2.0^{\mathrm{c}} & 0.0 \\ & 1 & 6.0 & - \\ \mathrm{D} 29-36 & 18 & 4.29^{\mathrm{a}} & 1.24 \\ \mathrm{D} 13-15 & 5 & 4.20^{\mathrm{ab}} & 1.30 \\ \mathrm{D} 16-23 & 17 & 4.00^{\mathrm{ab}} & 1.19 \\ \mathrm{D} 8-12 & 10 & 3.50^{\mathrm{bc}} & 0.71 \\ \mathrm{D} 24-28 & 13 & 3.69^{\mathrm{a}} & 1.08 \\ \mathrm{D} 1-7 & 12 & 3.67^{\mathrm{a}} & 1.07 \\ \mathrm{D} 37-39 & 3 & 2.67^{\mathrm{c}} & 1.53 \\ \mathrm{D} 40-47 & 11 & 2.73^{\mathrm{c}} & 1.49\end{array}$

Fig. 2. Simplified dendrogram based on the UPGMA clustering of similarity coefficients $\left(S_{\mathrm{D}}\right)$ of RAPD profiles of 126 strains of $B$. subtilis, obtained by using primers R1 and S1. For each primer, a similarity matrix was created and finally joined to a matrix, in which the respective value from each primer contributed to a mean. RAPD patterns were grouped into four major clusters, designated A through D, on the basis of $\geq 30 \%$ similarity (arbitrarily chosen) among the strains used. Grouped subdivisions within the predominant cluster D are shown, details of which are listed in Table $3 .{ }^{1} n=$ number of strains in (sub)cluster; ${ }^{2} \mathrm{AVG}=$ average functional score, see also Table $3 ;{ }^{3}$ S.D. $=$ standard deviation. Averages with the same superscript are not statistically different (unrelated two-tailed $t$-test at $5 \%$ level). 
Table 3

Bacillus subtilis isolates grouping based on UPGMA clustering of similarity coefficients of RAPD profiles (combined primers R1 and S1), with data of soybean fermentation characteristics

\begin{tabular}{|c|c|c|c|c|c|c|}
\hline \multirow[t]{2}{*}{ Strain code } & \multirow[t]{2}{*}{ Origin $^{\mathrm{a}}$} & \multirow[t]{2}{*}{ RAPD group ${ }^{b}$} & \multicolumn{4}{|c|}{ Selected functional characteristics } \\
\hline & & & $\overline{\mathrm{pH}}$ & Free amino groups (mM N/g) & Stickiness exopolymers (cm thread) & $\overline{\text { Score }^{\mathrm{c}}}$ \\
\hline 80 & $\mathrm{k}$ & A & 8.26 & 0.16 & 2 & 3 \\
\hline 75 & $\mathrm{k}$ & $\mathrm{B} 1$ & 8.09 & 0.34 & 1 & 2 \\
\hline 17 & $\mathrm{k}$ & $\mathrm{B} 2$ & 7.47 & 0.20 & 3 & 2 \\
\hline 32 & & & 7.73 & 0.17 & 3 & 2 \\
\hline 36 & & & 7.99 & 0.32 & 2 & 2 \\
\hline 67 & $\mathrm{k}$ & B3 & 7.85 & 0.37 & 3 & 2 \\
\hline 105 & $\mathrm{~s}$ & $\mathrm{C}$ & 8.33 & 0.51 & 8 & 6 \\
\hline 108 & $\mathrm{~s}$ & D1 & 8.40 & 0.46 & 1 & 3 \\
\hline 107 & $\mathrm{~s}$ & D2 & 8.53 & 0.71 & 2 & 5 \\
\hline 113 & $\mathrm{~s}$ & D3 & 8.03 & 0.66 & 1 & 4 \\
\hline 121 & $\mathrm{~s}$ & D4 & 8.23 & 0.41 & 2 & 4 \\
\hline 99 & $\mathrm{~s}$ & D5 & 8.43 & 0.51 & 1 & 4 \\
\hline 109 & & & 7.76 & 0.52 & 2 & 4 \\
\hline 111 & & & 7.82 & 0.34 & 5 & 4 \\
\hline 112 & & & 8.16 & 0.73 & 1 & 4 \\
\hline 100 & $\mathrm{~s}$ & D6 & 8.30 & 0.47 & 0.5 & 3 \\
\hline 116 & & & 7.44 & 0.35 & 1 & 1 \\
\hline 122 & & & 8.11 & 0.54 & 2 & 5 \\
\hline 104 & $\mathrm{~s}$ & D7 & 8.55 & 0.43 & 0.5 & 3 \\
\hline 19 & $\mathrm{k}$ & D8 & 8.20 & 0.45 & 3 & 4 \\
\hline 20 & & & 7.80 & 0.38 & 3 & 2 \\
\hline 21 & & & 8.01 & 0.46 & 5 & 4 \\
\hline 23 & & & 8.09 & 0.45 & 2 & 4 \\
\hline 24 & & & 8.00 & 0.48 & 3 & 4 \\
\hline 1 & $\mathrm{k}$ & D9 & 7.92 & 0.36 & 6 & 3 \\
\hline 4 & & & 7.83 & 0.62 & 8 & 3 \\
\hline 27 & $\mathrm{k}$ & D10 & 7.94 & 0.46 & 3 & 3 \\
\hline 38 & $\mathrm{k}$ & D11 & 8.03 & 0.31 & 4 & 4 \\
\hline 10 & $\mathrm{k}$ & D12 & 7.81 & 0.38 & 4 & 4 \\
\hline 30 & $\mathrm{k}$ & D13 & 8.35 & 0.49 & 3 & 4 \\
\hline 34 & & & 7.60 & 0.16 & 2 & 2 \\
\hline 45 & $\mathrm{k}$ & D14 & 8.50 & 0.63 & 3 & 5 \\
\hline 35 & $\mathrm{k}$ & D15 & 8.48 & 0.49 & 4 & 5 \\
\hline 40 & & & 8.48 & 0.46 & 4 & 5 \\
\hline 90 & $\mathrm{~s}$ & D16 & ND & ND & ND & ND \\
\hline 93 & & & 8.70 & 0.51 & 3 & 5 \\
\hline 110 & & & 8.45 & 0.57 & 6 & 6 \\
\hline 3 & $\mathrm{k}$ & D17 & 7.15 & 0.34 & 7 & 2 \\
\hline 5 & & & 7.50 & 0.36 & 6 & 3 \\
\hline 9 & & & 7.65 & 0.50 & 9 & 4 \\
\hline 14 & & & 7.95 & 0.43 & 4 & 4 \\
\hline 11 & $\mathrm{k}$ & D18 & 8.10 & 0.47 & 4 & 5 \\
\hline 13 & & & 7.78 & 0.39 & 9 & 3 \\
\hline 81 & & & 8.14 & 0.35 & 6 & 4 \\
\hline 25 & $\mathrm{k}$ & D19 & 7.83 & 0.43 & 3 & 2 \\
\hline 16 & $\mathrm{k}$ & D20 & 8.05 & 0.39 & 6 & 4 \\
\hline 76 & $\mathrm{k}$ & D21 & 8.21 & 0.43 & 3 & 4 \\
\hline 77 & & & 8.50 & 0.52 & 4 & 5 \\
\hline 78 & & & 8.44 & 0.44 & 2 & 4 \\
\hline 83 & & & 8.17 & 0.41 & 3 & 4 \\
\hline 117 & $\mathrm{~s}$ & D22 & 8.13 & 0.41 & 4 & 4 \\
\hline
\end{tabular}


Table 3 (continued)

\begin{tabular}{|c|c|c|c|c|c|c|}
\hline \multirow[t]{2}{*}{ Strain code } & \multirow[t]{2}{*}{ Origin $^{\mathrm{a}}$} & \multirow[t]{2}{*}{ RAPD group ${ }^{b}$} & \multicolumn{4}{|c|}{ Selected functional characteristics } \\
\hline & & & $\mathrm{pH}$ & Free amino groups (mM N/g) & Stickiness exopolymers (cm thread) & Score $^{\mathrm{c}}$ \\
\hline 74 & $\mathrm{k}$ & D23 & 7.83 & 0.34 & 5 & 5 \\
\hline 94 & $\mathrm{~s}$ & D24 & 8.61 & 0.32 & 3 & 3 \\
\hline 118 & & & 8.53 & 0.43 & 5 & 5 \\
\hline 91 & $\mathrm{~s}$ & D25 & 6.70 & 0.08 & 2 & 1 \\
\hline 52 & $\mathrm{k}$ & D26 & 8.08 & 0.48 & 4 & 4 \\
\hline 55 & & & 8.37 & 0.64 & 2 & 5 \\
\hline 66 & & & 8.23 & 0.34 & 2 & 3 \\
\hline 68 & & & 7.92 & 0.43 & 4 & 4 \\
\hline 72 & & & 8.39 & 0.39 & 4 & 3 \\
\hline 73 & & & 8.04 & 0.47 & 2 & 4 \\
\hline 18 & $\mathrm{k}$ & D27 & 7.64 & 0.37 & 8 & 3 \\
\hline 22 & & & 7.56 & 0.41 & 5 & 4 \\
\hline 33 & & & 8.39 & 0.43 & 4 & 4 \\
\hline 12 & $\mathrm{k}$ & D28 & 8.07 & 0.48 & 5 & 5 \\
\hline 56 & $\mathrm{k}$ & D29 & 8.34 & 0.53 & 2 & 5 \\
\hline 57 & & & 8.17 & 0.58 & 4 & 6 \\
\hline 125 & $\mathrm{~s}$ & D30 & 8.56 & 0.48 & 4 & 5 \\
\hline 126 & & & 8.58 & 0.50 & 6 & 5 \\
\hline 48 & $\mathrm{k}$ & D31 & 8.22 & 0.56 & 4 & 6 \\
\hline 54 & & & 8.13 & 0.63 & 2 & 5 \\
\hline 63 & & & 8.20 & 0.48 & 4 & 5 \\
\hline 51 & $\mathrm{k}$ & D32 & 8.37 & 0.69 & 3 & 5 \\
\hline 26 & $\mathrm{k}$ & D33 & 7.66 & 0.37 & 7 & 3 \\
\hline 39 & & & 7.81 & 0.23 & 6 & 3 \\
\hline 44 & & & 7.82 & 0.49 & 9 & 4 \\
\hline 46 & & & 7.60 & 0.42 & 11 & 4 \\
\hline 60 & & & 8.52 & 0.37 & 0 & 2 \\
\hline 49 & $\mathrm{k}$ & D34 & 7.87 & 0.56 & 0 & 3 \\
\hline 61 & $\mathrm{k}$ & D35 & 8.44 & 0.63 & 3 & 5 \\
\hline 62 & & & 7.46 & 0.48 & 5 & 4 \\
\hline 64 & & & 7.79 & 0.50 & 4 & 3 \\
\hline 53 & $\mathrm{k}$ & D36 & 7.87 & 0.59 & 6 & 5 \\
\hline 31 & $\mathrm{k}$ & D37 & 8.33 & 0.22 & 2 & 4 \\
\hline 65 & $\mathrm{k}$ & D38 & 8.13 & 0.47 & 2 & 4 \\
\hline 124 & $\mathrm{~s}$ & D39 & 7.19 & 0.31 & 1 & 1 \\
\hline 41 & $\mathrm{k}$ & D40 & 7.47 & 0.30 & 5 & 3 \\
\hline 42 & & & 7.82 & 0.45 & 4 & 4 \\
\hline 43 & & & 7.60 & 0.33 & 4 & 3 \\
\hline 50 & & & 7.58 & 0.46 & 3 & 3 \\
\hline 71 & $\mathrm{k}$ & D41 & 7.91 & 0.28 & 4 & 2 \\
\hline 82 & $\mathrm{k}$ & D42 & 7.87 & 0.31 & 4 & 3 \\
\hline 28 & $\mathrm{k}$ & D43 & 7.73 & 0.27 & 1 & 1 \\
\hline 7 & $\mathrm{k}$ & D44 & 7.17 & 0.25 & 3 & 1 \\
\hline 15 & $\mathrm{k}$ & D45 & 7.65 & 0.39 & 10 & 3 \\
\hline 69 & $\mathrm{k}$ & D46 & 7.62 & 0.25 & 1 & 1 \\
\hline 123 & $\mathrm{~s}$ & D47 & 8.67 & 0.65 & 9 & 6 \\
\hline
\end{tabular}

See also Fig. 2 for the simplified dendrogram.

${ }^{a}$ k: Kinema, s: Soumbala, r: reference strain.

b Capitals: distinction at $30 \%$ similarity. Numbers: distinction at $\geq 90 \%$ similarity.

c Scoring: total of scores for $\mathrm{pH}$, amino-N and stickiness: $\mathrm{pH}(<7.4=0 ; 7.4-8.0=1 ;>8.0=2)$, amino- $\mathrm{N}(<0.4=0 ; 0.4-0.5=1 ;>0.5=2)$, stickiness $(<1=0 ; 1-3=1 ;>4=2)$. 
prompted us to extend the dichotomous key of Slepecky and Hemphill (1992) embodying all 34 species of Bacillus described by Claus and Berkeley (1986), as shown in Table 1. The additional identification tests were chosen on the basis of their discriminatory power (Gower and Barnett, 1971). As our sampling was designed primarily to obtain as many different strains as possible, it is not possible to quantify the distribution of the various species in Kinema and Soumbala. Nevertheless, the number of strains of each species gives an indication of their relative abundance. $B$. subtilis had the highest occurrence in both Kinema and Soumbala (Table 2). From Kinema, B. subtilis, $B$. licheniformis, $B$. cereus, $B$. thuringiensis, $B$. circulans and $B$. sphaericus were isolated. The occurrence of $B$. subtilis and B. cereus in Kinema has been reported earlier (Sarkar et al., 1994; Nout et al., 1998). From Soumbala even more species including B. subtilis, $B$. thuringiensis, B. cereus, B. licheniformis, B. badius, B. alvei, B. firmus, B. larvae, B. laterosporus, B. megaterium, $B$. sphaericus and $B$. mycoides were isolated. Ogbadu and Okagbue (1988b) isolated $B$. pumilus and B. licheniformis, in addition to B. subtilis, from fermented locust beans, and B. mycoides from unsuccessful fermentations.

For RAPD analysis primers R1 and S1 were selected because they gave patterns for a wide range of Bacillus spp. reference strains, and they yielded distinctly different patterns. The majority of the isolates could be distinguished by their RAPD profiles. The isolates which could not be separated by this technique originated from the same food sample and were likely to be the same strain picked more than once during the isolation.

In order to enhance resolution between the $B$. subtilis strains, the data from RAPD patterns obtained with the two primers were combined in a single dendrogram. Fig. 2 shows a simplified version of the dendrogram obtained. Basically, the combined profiles could be grouped into four major clusters emerging at a similarity level of $30 \%$. These clusters, designated $\mathrm{A}$ through $\mathrm{D}$, represented $1 \%, 5 \%, 1 \%$ and $93 \%$ of the B. subtilis strains, respectively. Of these clusters $\mathrm{A}, \mathrm{B}$ and $\mathrm{C}$ were homogeneous source and continent-wise. With more than $90 \%$ similarity, the clusters $\mathrm{B}$ and $\mathrm{D}$ could again be divided into three $\left(B_{1}-B_{3}\right)$ and $47\left(D_{1}-D_{47}\right)$ subdivisions, respectively. In Fig. 2, the branching into subdivisions is shown for the predominant cluster D. Table 3 lists the distribution of strains in subdivisions. Of these 52 subdivisions, 32 consisted of only one strain each, whereas the remaining 20 subdivisions totalling 65 strains consisted of two to seven strains each. These multistrain subdivisions were all homogenous source and continent-wise. A similar high degree of genetic heterogeneity, using RAPD fingerprints was observed in B. thuringiensis (Brousseau et al., 1993) and B. cereus (Stephan, 1996). The wide extent of genetic diversity observed using RAPD can be partially explained by the presence of extrachromosomal plasmids larger than $20 \mathrm{kbp}$ that can compete with the genomic DNA in the annealing phase, giving fragments which are amplified only in the strains harbouring that plasmid (Daffonchio et al., 1998). This indicates that strain to strain variability in RAPD profiles with a particular species can be partially explained by the presence or absence of plasmid DNA.

Twenty-one strains of B. subtilis were selected from six RAPD subdivisions for the evaluation of their carbon source fermentation using the API system, and to observe possible relationships between RAPD and fermentation groups. While two pairs (isolate codes 19 and 23, and 66 and 83) had identical fermentation patterns, the remaining strains had individually slightly different fermentation profiles. Of 49 carbon sources, none of the strains of B. subtilis was able to utilize erythritol, D-arabinose, L-xylose, adonitol, $\beta$-methyl-D-xyloside, galactose, sorbose, rhamnose, dulcitol, $\alpha$-methyl-D-mannoside, $N$-acetyl glucosamin, amygdalin, arbutin, salicin, xylitol, $\beta$ gentiobiose, D-lyxose, D-tagatose, D-fucose, L-fucose, D-arabitol, L-arabitol, gluconate, 2-ketogluconate and 5-ketogluconate, whereas all fermented sucrose.

On the basis of their fermentation profiles, the isolates were combined when their fermentation profiles showed maximum three different reactions (similarity $\geq 46 / 49$ or $\geq 94 \%$ ). In Table 4 , the relationship between RAPD subdivisions and these groups of similar fermentation profiles is shown. A good correlation was observed between RAPD subdivisions D8, D17, D21, and D27 and their fermentation profiles. On the other hand, some discrepancies occur such as isolates 99 and 122 having highly similar fermentation profiles but belonging to neighbouring RAPD subdivisions. A similar case is isolate 66 (subdivision 
Table 4

Comparison of subdivisions of selected strains of Bacillus subtilis obtained using RAPD-PCR and fermentation profiling fingerprint approaches

\begin{tabular}{|c|c|c|c|c|c|c|c|c|c|c|c|c|c|c|c|c|c|c|c|c|c|c|c|c|c|}
\hline \multirow{2}{*}{$\begin{array}{l}\text { Strain } \\
\text { code }\end{array}$} & \multirow{2}{*}{$\begin{array}{l}\text { RAPD } \\
\text { profile }^{\text {a }}\end{array}$} & \multicolumn{24}{|c|}{ Fermentation of carbon sources } \\
\hline & & Profile $^{b}$ & $1^{\mathrm{c}}$ & 4 & 5 & 6 & 11 & 12 & 13 & 17 & 18 & 19 & 21 & 25 & 27 & 28 & 29 & 30 & 32 & 33 & 34 & 35 & 36 & 37 & 40 \\
\hline 109 & D5 & I & + & + & - & - & + & + & - & - & - & - & + & - & - & + & - & - & + & + & - & + & + & + & - \\
\hline 99 & D5 & II & + & - & - & - & - & + & - & - & - & - & - & + & - & + & - & - & - & - & - & - & - & - & - \\
\hline 122 & D6 & II & + & - & - & - & - & + & - & + & - & - & - & - & - & + & - & - & + & - & - & - & - & - & - \\
\hline 100 & D6 & III & + & + & - & - & + & + & + & + & - & - & - & - & - & + & - & - & - & + & - & + & + & + & - \\
\hline 116 & D6 & IV & - & + & - & - & - & + & - & - & - & - & - & + & - & + & - & + & - & + & - & + & + & + & - \\
\hline 3 & D17 & $\mathrm{V}$ & + & + & - & + & + & + & + & + & - & - & + & + & - & + & - & + & + & - & - & + & + & + & + \\
\hline 5 & D17 & $\mathrm{V}$ & + & + & - & + & + & + & + & + & - & - & + & + & - & + & - & + & + & - & - & + & + & + & - \\
\hline 9 & D17 & $\mathrm{V}$ & + & + & - & - & + & + & + & + & - & - & + & + & + & + & - & + & + & - & - & + & + & + & + \\
\hline 14 & D17 & $\mathrm{V}$ & + & + & + & + & + & + & + & + & - & - & + & + & - & + & - & + & + & - & - & + & + & + & + \\
\hline 76 & D21 & VI & + & + & + & - & + & + & + & + & + & + & - & + & - & + & - & + & + & + & - & + & + & + & - \\
\hline 77 & D21 & VI & + & + & + & + & + & + & + & + & + & + & - & + & - & - & - & - & + & + & - & + & - & + & - \\
\hline 78 & D21 & VI & + & + & + & + & + & + & + & + & + & + & + & + & - & + & + & + & + & + & - & + & + & + & - \\
\hline 83 & D21 & VI & + & + & + & + & + & + & + & + & + & + & + & + & - & + & - & + & + & + & - & + & + & + & + \\
\hline 66 & D26 & VI & + & + & + & + & + & + & + & + & + & + & + & + & - & + & - & + & + & + & - & + & + & + & + \\
\hline 68 & D26 & VII & + & + & + & + & + & + & - & + & + & + & + & + & - & + & - & + & + & + & - & + & + & - & - \\
\hline 18 & D27 & VII & + & + & + & - & + & - & - & + & + & + & + & + & - & + & - & + & + & + & - & + & + & - & - \\
\hline 22 & D27 & VII & + & + & + & + & + & + & - & + & + & + & + & + & - & + & - & + & + & + & + & + & + & - & + \\
\hline 19 & D8 & VIII & + & + & - & - & + & + & + & + & + & + & + & + & - & + & - & + & + & + & - & + & + & - & + \\
\hline 21 & D8 & VIII & + & + & + & - & + & + & + & + & + & + & + & + & - & + & - & + & + & + & - & + & + & - & + \\
\hline 23 & D8 & VIII & + & + & - & - & + & + & + & + & + & + & + & + & - & + & - & + & + & + & - & + & + & - & + \\
\hline 24 & D8 & VIII & + & + & + & - & + & + & + & + & + & + & + & + & - & + & - & + & + & + & + & + & + & - & + \\
\hline
\end{tabular}

${ }^{\text {a }}$ Subdivisions at $\geq 90 \%$ similarity.

b Profiles with similarity $\geq 94 \%$.

c 1-glycerol, 4-L-arabinose, 5-ribose, 6-D-xylose, 11-D-glucose, 12-D-fructose, 13-D-mannose, 17-inositol, 18-mannitol, 19sorbitol, $21-\alpha$-methyl-D-glucoside, 25-esculin, 27-cellobiose, 28-maltose, 29-lactose, 30-melibiose, 32-trehalose, 33-inuline, 34melezitose, 35-D-raffinose, 36-starch, 37-glycogen, 40-D-turanose.

D26) with fermentation profile, corresponding with the isolates of RAPD subdivision D21. Even though not all isolates were tested for their fermentation profile this limited analysis suggests that RAPD fingerprinting and comparison of fermentation profiles based on 50 carbon sources have discriminatory capacity of a similar order of magnitude.

The high number of different Bacillus strains isolated from Kinema and Soumbala confirms the diversity of the microflora and the need for effective methods for selection and control of starter cultures at subspecies level. Experimental soybean fermentations with the pure strains were carried out. All strains multiplied as expected and fermented soybeans were scored for $\mathrm{pH}$, free amino- $\mathrm{N}$ and stickiness as shown in Table 3. Whereas some correlation $\left(r^{2}=0.51\right)$ was observed between increasing $\mathrm{pH}$ and level of free amino-N, no correlations between $\mathrm{pH}$ and stickiness, or free amino-N and stickiness were evident. Of the
RAPD groups containing several strains, B2, D8, D9, D15, D16, D21, D29, D30 and D33 showed a homogenous pattern of soybean fermentation. On the other hand some groups such as D5, D6, D17, D18 and D26 showed more variability. The total scores and their standard deviation (Fig. 2) illustrate these differences in homogeneity. Fig. 2 reveals that certain genotypic clusters (C, D29-D36, D13-D15, D16-D23, D24-D28 and D1-D7) gave medium to high scores whereas others $(\mathrm{A}, \mathrm{B}, \mathrm{D} 8-\mathrm{D} 12, \mathrm{D} 37-$ D39 and D40-D47) performed poorly. Even though the number of strains tested for their fermentation profile is limited, it appears that groups I, II, VI and VIII (Table 4) are associated with relatively high quality scores (Table 3). Whereas this knowledge will be useful in screening and comparative studies of high-quality starter strains, final strain selection will still depend on individual performance of strains under practical conditions, also considering additional 
factors such as the production of desirable volatile aroma, and competitiveness in the presence of contaminating microflora.

\section{Acknowledgements}

The financial support from the International Foundation for Science, Stockholm, Sweden, and the governments of India and the Netherlands under the framework of Indo-Netherlands Cultural Exchange Programme is gratefully acknowledged. The authors would like to thank Erik van Bommel and Carmen Gil for technical contributions, and Dr. Meike te Giffel of the Netherlands Institute for Dairy Research (NIZO), Ede, The Netherlands, and Dr. L.K. Nakamura of the National Center for Agricultural Utilization Research, Peoria, IL, USA, for helpful discussions.

\section{References}

Antai, S.P., Ibrahim, M.H., 1986. Micro-organisms associated with African locust bean (Parkia filicoidea Welw) fermentation for 'dawadawa' production. J. Appl. Bacteriol. 61, 145-148.

Brousseau, R., Saint-Onge, A., Prefontaine, G., Masson, L., Cabana, J., 1993. Arbitrary primer polymerase chain reaction, a powerful method to identify Bacillus thuringiensis serovars and strains. Appl. Environ. Microbiol. 59, 114-119.

Campbell-Platt, G., 1987. Fermented Foods of the World-A Dictionary and Guide: Butterworths, London.

Claus, D., Berkeley, R.C.W., 1986. Genus Bacillus Cohn 1872, 174. In: Sneath, P.H.A., Mair, N.S., Sharpe, M.E., Holt, J.G. (Eds.), Bergey's Manual of Systematic Bacteriology, vol. 2. Williams \& Wilkins, Baltimore, MD, pp. 1105-1139.

Daffonchio, D., Borin, S., Frova, G., Manachini, P.L., Sorlini, C., 1998. PCR fingerprinting of whole genome: the spacers between the $16 \mathrm{~S}$ and $23 \mathrm{~S}$ rRNA genes and of intergenic tRNA gene regions reveal a different intraspecific genomic variability of Bacillus cereus and Bacillus licheniformis. Int. J. Syst. Bacteriol. 48, 107-116.

Deák, T., Timár, E., 1988. Simplified identification of aerobic sporeformers in the investigation of foods. Int. J. Food Microbiol. 6, $115-125$.

Euzéby, J.P., 1997. List of bacterial names with standing in nomenclature: a folder available on the Internet (URL: http://www. bacterio.cict.fr/). Int. J. Syst. Bacteriol. 47, 590-592.

Gower, J.C., Barnett, J.A., 1971. Selecting tests in diagnostic keys with unknown responses. Nature 232, 491-493.

Hilton, A.C., Banks, J.G., Penn, C.W., 1996. Random amplification of polymorphic DNA (RAPD) of Salmonella: strain differentia- tion and characterization of amplified sequences. Journal of Applied Bacteriology 81, 575-584.

Mileham, A.J., 1997. Protocol: identification of microorganisms using random primed PCR. Mol. Biotechnol. 8, 139-145.

Nout, M.J.R., Bakshi, D., Sarkar, P.K., 1998. Microbiological safety of Kinema, a fermented soya bean food. Food Control 9, 357362.

Odunfa, S.A., 1981. Microorganisms associated with fermentation of African locust bean (Parkia filicoidea) during iru preparation. J. Plant Foods 3, 245-250.

Odunfa, S.A., 1986. Dawadawa. In: Reddy, N.R., Pierson, M.D., Salunkhe, D.K. (Eds.), Legume-Based Fermented Foods. CRC Press, Boca Raton, FL, USA, pp. 173-189.

Ogbadu, L.J., Okagbue, R.N., 1988a. Bacterial fermentation of soya bean for "daddawa" production. J. Appl. Bacteriol. 65, 353356.

Ogbadu, L.J., Okagbue, R.N., 1988b. Fermentation of African locust bean (Parkia biglobosa) seeds: involvement of different species of Bacillus. Food Microbiol. 5, 195-199.

Owens, J.D., Allagheny, N., Kipping, G., Ames, J.M., 1997. Formation of volatile compounds during Bacillus subtilis fermentation of soya beans. J. Sci. Food Agric. 74, 132-140.

Sarkar, P.K., Tamang, J.P., 1994. The influence of process variables and inoculum composition on the sensory quality of Kinema. Food Microbiol. 11, 317-325.

Sarkar, P.K., Tamang, J.P., Cook, P.E., Owens, J.D., 1994. Kinema-a traditional soybean fermented food: proximate composition and microflora. Food Microbiol. 11, 47-55.

Slepecky, R.A., Hemphill, H.E., 1992. The genus Bacillus-nonmedical. In: Balows, A., Trüper, H.G., Dworkin, M., Harder, W., Schleifer, K.-H. (Eds.), The Prokaryotes, A Handbook on the Biology of Bacteria: Ecophysiology, Isolation, Identification, Applications, 2nd edn., vol. 2. Springer-Verlag, New York, pp. $1663-1696$.

Steinkraus, K.H., 1995. Indigenous fermented foods involving an alkaline fermentation. In: Steinkraus, K.H. (Ed.), Handbook of Indigenous Fermented Foods, 2nd edn. Marcel Dekker, New York, pp. 349-362.

Stephan, R., 1996. Randomly amplified polymorphic DNA (RAPD) assay for genomic fingerprinting of Bacillus cereus isolates. Int. J. Food Microbiol. 31, 311-316.

Stephan, R., Schraft, H., Untermann, F., 1994. Characterization of Bacillus licheniformis with the RAPD technique (randomly amplified polymorphic DNA). Lett. Appl. Microbiol. 18, 260-263.

Tamang, J.P., 1999. Development of pulverised starter for Kinema production. J. Food Sci. Technol. 36, 475-478.

Tamang, J.P., Nikkuni, S., 1996. Selection of starter cultures for the production of Kinema, a fermented soybean food of the Himalaya. World J. Microbiol. Biotechnol. 12, 629-635.

Tamang, J.P., Sarkar, P.K., Hesseltine, C.W., 1988. Traditional fermented foods and beverages of Darjeeling and Sikkim-a review. J. Sci. Food Agric. 44, 375-385.

Te Giffel, M.C., Beumer, R.R., Klijn, N., Wagendorp, A., Rombouts, F.M., 1997. Discrimination between Bacillus cereus and Bacillus thuringiensis using specific DNA probes based on variable regions of 16SrRNA. FEMS Microbiology Letters 146, $47-51$. 